\title{
Differential effects of hyaluronan synthase 3 deficiency after acute vs chronic liver injury in mice
}

\author{
Jennifer M. McCracken", Lu Jiang ${ }^{1}$, Krutika T. Deshpande', Maura F. O'Neil ${ }^{2}$ and Michele T. Pritchard ${ }^{1 *}$ (D)
}

\begin{abstract}
Background: Hyaluronan (HA) is a ubiquitous extracellular matrix (ECM) glycosaminoglycan synthesized by three different enzymes, hyaluronan synthase (HAS)1, 2, and 3. HA synthesis mediated by HAS3 promotes inflammation and is pathogenic in animal models of human lung and intestinal disease. Liver fibrosis is a common endpoint to chronic liver injury and inflammation for which there is no cure. Although plasma HA is a commonly used biomarker for liver disease, if and how HA contributes to disease pathogenesis remains unclear. Here, we tested the hypothesis that HA synthesized by HAS3 enhances inflammation and fibrosis. To test this hypothesis, we exposed wild-type or Has3-/- mice to carbon tetrachloride $\left(\mathrm{CCl}_{4}\right)$ once (acute) or ten (chronic) times.

Results: HAS3-deficient mice exhibited increased hepatic injury and inflammatory chemokine production $48 \mathrm{~h}$ after acute $\mathrm{CCl}_{4}$; this was associated with a threefold reduction in plasma $\mathrm{HA}$ levels and alterations in the proportions of specific molecular weight HA polymer pools. Hepatic accumulation of fibrosis-associated transcripts was also greater in livers from HAS3-deficient mice compared to controls after acute $\mathrm{CCl}_{4}$ exposure. Surprisingly, fibrosis was not different between genotypes. Hepatic matrix metalloproteinase (MMP)13 mRNA and MMP13 activity was greater in livers from Has3-null mice after chronic $\mathrm{CCl}_{4}$; this was prevented by a MMP13-specific inhibitor. Collectively, these data suggest that Has3, or more likely HA produced by HAS3, limits hepatic inflammation after acute injury and attenuates MMP13-mediated matrix metabolism after chronic injury.
\end{abstract}

Conclusions: These data suggest that HA should be investigated further as a novel therapeutic target for acute and chronic liver disease.

Keywords: Fibrosis, Hyaluronan, Inflammation, Liver, Matrix metalloproteinase 13

\section{Background}

Liver fibrosis is the end result of chronic hepatic injury and inflammation coupled with incomplete tissue repair. The net effect of incomplete repair over several cycles of tissue injury is accumulation of extracellular matrix (ECM) proteins. When prolonged, excessive ECM accumulation impacts hepatic architecture and function. Several agents cause liver fibrosis including alcohol, obesity, viruses, congenital disorders, cholestasis, parasites, drugs, and toxins $[1,2]$. Regardless of etiologic agent, the progression to liver fibrosis occurs in only a subset of patients and is affected by a host of additional factors including

\footnotetext{
* Correspondence: mpritchard@kumc.edu

'Department of Pharmacology, Toxicology and Therapeutics, University of Kansas Medical Center, Kansas City, KS 66160, USA

Full list of author information is available at the end of the article
}

genetics, environment, behavior, and various comorbidities [3]. While removal of the etiologic agent can attenuate disease progression and even lead to fibrosis reversal in some patients, no pharmacologic strategy yet exists to "cure" advanced liver disease $[4,5]$. Liver transplantation is the only therapeutic option for advanced liver disease not responsive to etiologic agent removal.

Hyaluronan (HA) is a non-sulfated, anionic glycosaminoglycan which consists of repeating $\mathrm{N}$-acetylglucosamine and glucuronic acid disaccharide units [6]. Three HA synthases exist in mammals: (HAS)1, 2, and 3 [7]. They differ based on biosynthetic capacity, length of the HA polymer synthesized, induction profiles, and tissue expression levels [7-9]. Generally speaking, HA is synthesized as a high molecular weight (HMW) polymer by many cell types including fibroblasts and vascular endothelial cells 
$[10,11]$. When tissues are injured, HA is synthesized and degraded and participates in the wound healing response [11]. HMW-HA (250-2000 kDa) is a major component of healthy articular joints, the vitreous humor of the eye, and the skin and when synthesized in these injured tissues, dampens inflammation [12]. HA is degraded by hyaluronidases and reactive oxygen species under normal circumstances and also when tissues are injured into a polydisperse population containing low molecular weight (LMW) fragments $(<250 \mathrm{kDa})$ which exacerbate inflammation [12]. Persistence of LMW-HA in chronically wounded tissue contributes to disease pathogenesis in animal models of idiopathic pulmonary fibrosis [13]. Of the hyaluronan synthases, HAS3 makes the smallest HA polymers ranging from 100 to $1000 \mathrm{kDa}$, which includes polymers in the LMW range [8]. Consistently, published studies using animal models of human lung and intestine disease show that HA synthesized by HAS3 contributes to inflammation [14-16].

HA is used as a biomarker for liver disease severity; the more advanced the liver disease, the greater the amount of HA is found in the blood $[17,18]$. This is likely due to a combination of increased HA synthesis by hepatic stellate cells and other cells $[19,20]$, as well as a reduced capacity for HA uptake by dysfunctional liver sinusoidal endothelial cells found in diseased liver [21]. Despite the relationship between plasma HA levels and liver disease and the proinflammatory role HA plays in other diseases, no studies have determined whether or not HA has a direct role in liver disease pathogenesis. In this study, we tested the hypothesis that HAS3, or HA produced by HAS3, contributes to liver inflammation and fibrosis by increasing the proportion of LMW-HA polymers relative to HMW-HA polymers. To test this hypothesis, we utilized the wellcharacterized carbon tetrachloride $\left(\mathrm{CCl}_{4}\right)$-induced liver injury and fibrosis model in wild-type mice and mice deficient in HAS3 [22]. Due to a lack of HA synthesized by HAS3, we predicted Has3-/- mice would exhibit reduced inflammation and fibrosis after $\mathrm{CCl}_{4}$ exposure, similar to the previously published studies [14-16]. Here, we provide evidence that HAS3 plays divergent roles depending upon whether liver injury is acute or chronic.

\section{Results}

Hepatic Has gene transcript accumulation and plasma HA levels in wild-type and Has3-/- mice

Real-time polymerase chain reaction (PCR) was used to determine the relative amounts of Has1, 2, and 3 in the livers from wild-type and Has3-/- mice, at baseline. The accumulation of Has1 transcripts was not different between genotypes (Fig. 1a). Has3 transcripts were most abundant in the livers from the wild-type mice and were approximately fivefold more than Has1 transcripts. Has2 transcripts were least abundant in both genotypes, between 1 and $5 \%$ of total Has 1 levels. However, Has2, was 40 \% greater in livers

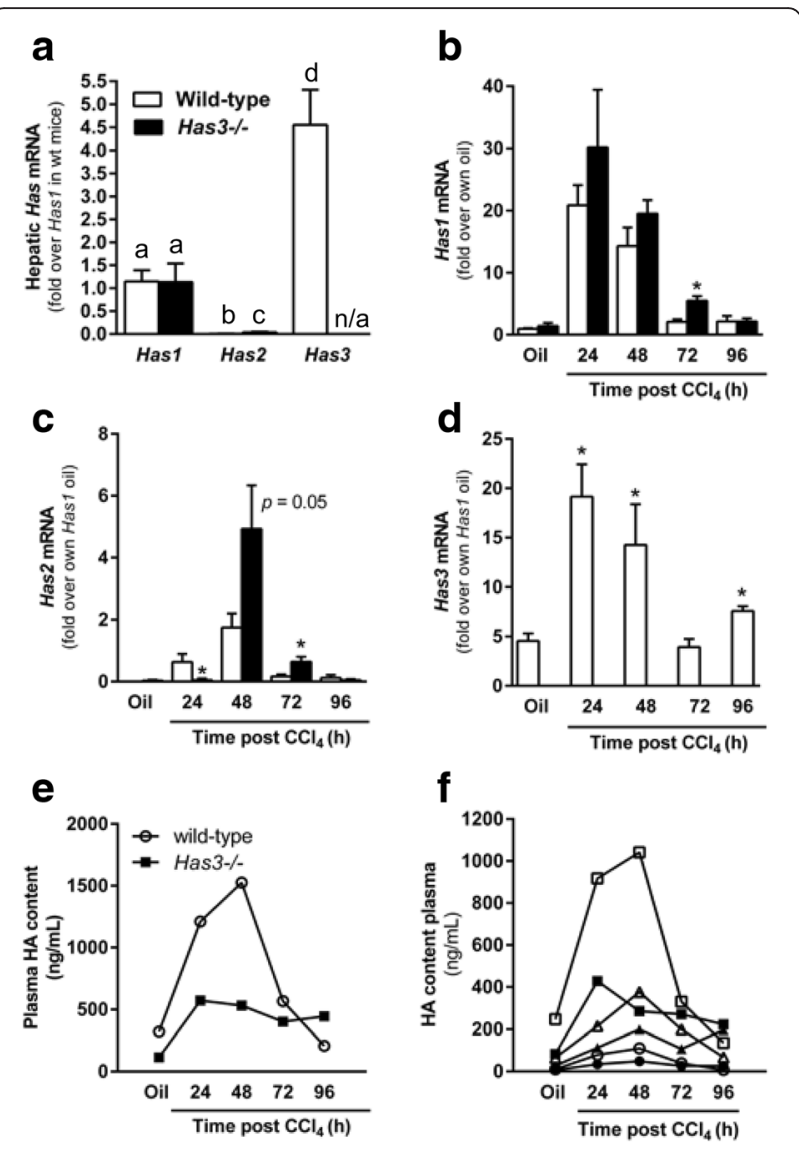

Fig. 1 Hepatic Has enzymes and plasma HA levels in wild-type and Has3-/- mice. a Real-time PCR was used to measure basal levels of hepatic Has enzyme transcript accumulation in the wild-type and Has3-/- mice. Data were normalized to 185 and then expressed as fold change over wild-type hepatic Has 1 content. Bars with different alphabetical superscripts are significantly different from one another $(P<0.05)$. b- $\mathbf{d}$ The mice were exposed to $\mathrm{CCl}_{4}$ and euthanized 24, 48,72 , or 96 h later. Control animals received an olive oil (oil) injection. Real-time PCR was used to measure hepatic Has 1 (b), Has2 (c), and Has3 (d) in the livers from the wild-type and HAS3-deficient mice. ${ }^{*} P<0.05$ when compared to the wild-type mice at the same time point. An ELISA-like assay (see the "Methods" section for details on this antibody-independent assay) was used to determine HA concentration in pooled plasma from the wild-type and Has3-/- mice either before (e) or after (f) HA fractionation using molecular weight cut-off columns. In $\mathbf{e}$ and $\mathbf{f}$, the open symbols indicate wild-type mice while the closed symbols indicate Has3-/- mice. Circles indicate HA pools less than $100 \mathrm{kDa}$, squares indicate HA pools between 100 and $300 \mathrm{kDa}$, and triangles indicate HA pools greater than $300 \mathrm{kDa}$. Statistical analysis was not performed on these pooled samples. See Table 1 for additional details. $n / a$ not applicable. $N=6-8$ mice per experimental group

from Has3-/- mice relative to wild-type mice suggesting this enzyme may compensate, at least in part, for HAS3 deficiency at baseline.

Real-time PCR was again used to evaluate hepatic Has gene transcript levels after acute $\mathrm{CCl}_{4}$ exposure. In wildtype mice, Has1 levels were increased 20-fold above baseline $24 \mathrm{~h}$ after $\mathrm{CCl}_{4}$ exposure and declined thereafter 
(Fig. 1b). In the Has3-/- mice, hepatic Has1 transcripts also increased $24 \mathrm{~h}$ after $\mathrm{CCl}_{4}$ exposure, but this level was not different from that found in the wild-type mice (Fig. 1b). Has 1 transcripts were greater in the livers from the Has3 $-/-$ mice relative to the wild-type mice $72 \mathrm{~h}$ after $\mathrm{CCl}_{4}$ exposure. Has 2 transcripts peaked in the wild-type mice $48 \mathrm{~h}$ after $\mathrm{CCl}_{4}$ exposure, but only 1.8 -fold above baseline (Fig. 1c). Unlike Has2 transcripts in the wild-type mice, Has 2 transcripts were not induced in the Has3-/- mice until $48 \mathrm{~h}$ after $\mathrm{CCl}_{4}$ exposure (Fig. 1c). At this time point, Has 2 transcripts increased fivefold in the Has3-/- mice, but this increase was not significantly different than that found in the wild-type mice ( $P=0.05$, Fig. $1 c)$. However, Has 2 transcripts were greater in the Has3-/- mice compared to the wild-type mice $72 \mathrm{~h}$ after $\mathrm{CCl}_{4}$ exposure (Fig. 1c). Finally, Has3 transcripts were induced approximately 20-fold over baseline 24 and $48 \mathrm{~h}$ after $\mathrm{CCl}_{4}$ exposure in wild-type mice and returned to baseline $72 \mathrm{~h}$ after $\mathrm{CCl}_{4}$ and increased again $96 \mathrm{~h}$ after $\mathrm{CCl}_{4}$ (Fig. 1d). Taken together, acute $\mathrm{CCl}_{4}$ exposure induced all three Has transcripts in the liver; Has1 and Has3 were most robustly induced.

Using an enzyme-linked immunosorbent assay (ELISA)like assay, we measured plasma HA levels in the wild-type and Has3-/- mice. The Has3-/- mice had reduced plasma HA levels when compared to the wild-type mice at baseline, $24 \mathrm{~h}$, and $48 \mathrm{~h}$ after $\mathrm{CCl}_{4}$ exposure (Fig. 1e). HA levels were similar between genotypes at $72 \mathrm{~h}$ but greater in the Has3-/- mice $96 \mathrm{~h}$ after $\mathrm{CCl}_{4}$ exposure (Fig. 1e). These data suggested that other HAS enzymes did not completely compensate for reduced HA biosynthetic capacity found in the Has3-/- mice. Next, using specific molecular weight cut-off columns to fractionate plasma $\mathrm{HA}$ into three groups $(<100 \mathrm{kDa}, 100-300 \mathrm{kDa}$, and $>300 \mathrm{kDa}$ ), we found that the wild-type mice had more $\mathrm{HA}$ in the $100-300 \mathrm{kDa}$ molecular weight range, compared to the Has3-/- mice, while the absolute amounts of $\mathrm{HA}$ in the other fractions did not exhibit such large differences between genotypes (Fig. 1f). The majority of plasma HA was found in the $100-300 \mathrm{kDa}$ fraction in the wild-type and Has3-/- mice (Fig. 1f and Table 1). However, relative to wild-type mice, the Has3-/- mice exhibited an increased percentage of the $<100 \mathrm{kDa} H A$ fraction, decreased percentage of the $100-300 \mathrm{kDa}$ fraction, and increased percentage of the $>300 \mathrm{kDa} H A$ fraction at almost every time point after $\mathrm{CCl}_{4}$ exposure (Table 1). These data suggested that, in addition to a reduction in total HA level, HA molecular mass distribution was also perturbed in the Has3-/- mice, favoring lower molecular weight populations, relative to the wild-type mice.

\section{Liver injury and steatosis after acute $\mathrm{CCl}_{4}$ exposure}

The wild-type and Has3-/- mice were exposed to $\mathrm{CCl}_{4}$ and euthanized 24, 48, 72, and $96 \mathrm{~h}$ later. $\mathrm{CCl}_{4}$ induced liver injury in both strains of mice, but this injury was greater in the livers from the Has3-/- mice. Specifically, peak plasma alanine aminotransferase (ALT) activity, a measure of liver injury, was $41 \%$ greater in the Has3-/mice relative to the control mice $48 \mathrm{~h}$ after $\mathrm{CCl}_{4}$ exposure (Fig. 2a). Although plasma ALT activity was reduced $72 \mathrm{~h}$ after $\mathrm{CCl}_{4}$ in both strains, it remained greater in the Has3 -/- mice (Fig. 2a). In support of these data, histopathological assessment revealed more necrosis in the livers from the Has3-/- mice compared to the wild-type mice (Fig. 2b). Hepatic triglyceride accumulation increased $24 \mathrm{~h}$ after $\mathrm{CCl}_{4}$ but was $31 \%$ greater in the HAS3-deficient mice compared to the controls (Fig. 2c). Liver histology paralleled these two biochemical measures of the liver's response to $\mathrm{CCl}_{4}$ in the wild-type and Has3-/- mice (Fig. 2d). Increased macrovesicular steatosis was more abundant in the livers from the Has3-/- mice compared to the wild-type mice $24 \mathrm{~h}$ after $\mathrm{CCl}_{4}$. Consistent with increased plasma ALT values, hepatic architecture was more severely disrupted in the Has3-/mice $48 \mathrm{~h}$ after $\mathrm{CCl}_{4}$ exposure. Fewer hepatocyte nuclei and more hemorrhage were present in the necrotic areas of

Table 1 Total and fractionated plasma HA content in wild-type and Has3-/- mice after acute carbon tetrachloride exposure

\begin{tabular}{|c|c|c|c|c|c|c|c|}
\hline Group & $<100 \mathrm{kDa}(\mathrm{ng} / \mathrm{mL})$ & $\%$ of total & $100-300 \mathrm{kDa}(\mathrm{ng} / \mathrm{mL})$ & $\%$ of total & $>300$ kDa $(\mathrm{ng} / \mathrm{mL})$ & $\%$ of total & Total $(\mathrm{ng} / \mathrm{mL})$ \\
\hline \multicolumn{8}{|c|}{ Wild-type mice } \\
\hline Oil & 10 & 3 & 247 & 77 & 64 & 20 & 322 \\
\hline $24 \mathrm{~h}$ & 78 & 6 & 917 & 76 & 215 & 18 & 1210 \\
\hline $48 \mathrm{~h}$ & 109 & 7 & 1041 & 68 & 376 & 25 & 1526 \\
\hline $72 \mathrm{~h}$ & 38 & 7 & 330 & 58 & 199 & 35 & 567 \\
\hline $96 \mathrm{~h}$ & 7 & 3 & 135 & 65 & 66 & 32 & 208 \\
\hline \multicolumn{8}{|c|}{ Has3-/- mice } \\
\hline Oil & 6 & 5 & 82 & 71 & 27 & 23 & 115 \\
\hline $24 \mathrm{~h}$ & 34 & 3 & 428 & 75 & 112 & 20 & 574 \\
\hline $48 \mathrm{~h}$ & 48 & 9 & 285 & 54 & 199 & 37 & 532 \\
\hline $72 \mathrm{~h}$ & 26 & 7 & 271 & 67 & 106 & 26 & 403 \\
\hline $96 \mathrm{~h}$ & 26 & 6 & 223 & 50 & 196 & 44 & 445 \\
\hline
\end{tabular}



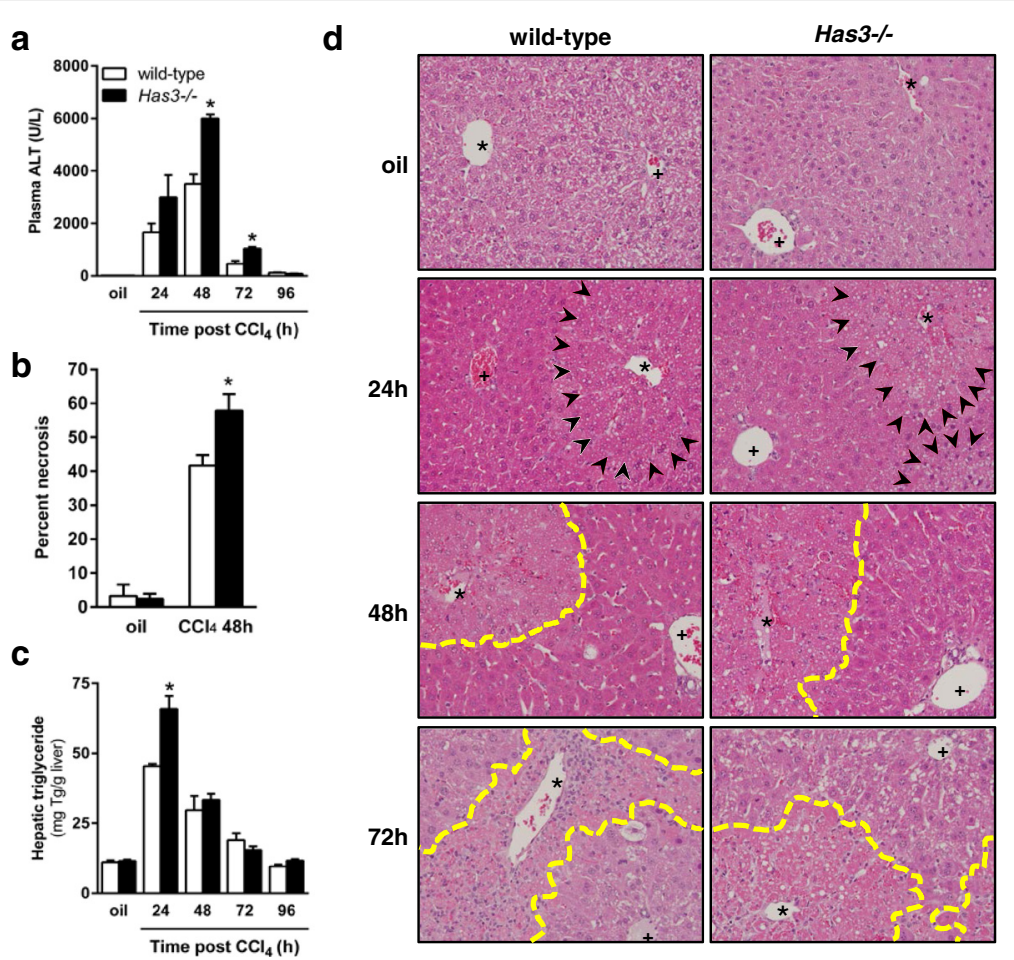

Fig. 2 Liver injury and steatosis in wild-type and Has3-/- mice. The mice were exposed to $\mathrm{CCl}_{4}$ and euthanized 24, 48, 72, or $96 \mathrm{~h}$ later. Control animals received an olive oil (oil) injection. a Plasma ALT activity was determined using an enzymatic assay. $\mathbf{b}$ Histopathologic assessment of the percent necrosis at baseline and $48 \mathrm{~h}$ after $\mathrm{CCl}_{4}$ exposure. c Total hepatic triglycerides were measured using a biochemical assay. $\mathbf{d}$ Representative histology in the wild-type and Has3-/- mice (200x). Asterisks denote central veins, and plus signs denote the portal vein of the portal triad. The necrotic areas are outlined with yellow dashed line in the 48 and $72 \mathrm{~h}$ images, and the area of macrovesicular steatosis is identified by black arrows in the $24 \mathrm{~h}$ images. In every figure of this manuscript, white bars indicate wild-type mice while black bars indicate Has $3-/-$ mice. ${ }^{*} P<0.05$ compared between genotypes at the same time point. $N=4-7$ mice per experimental group

the Has3-/- mice compared to the wild-type mice. Seventy-two hours after $\mathrm{CCl}_{4}$, robust cellular infiltration was found in the pericentral areas of the wild-type mice; this infiltration was reduced in the livers from the Has3-/mice and was associated with more eosinophilic staining in the pericentral areas (Fig. 2d). Ninety-six hours after $\mathrm{CCl}_{4}$ exposure, liver histology was largely back to normal and not different between genotypes (data not shown).

$\mathrm{CCl}_{4}$ must be bioactivated to reactive metabolites to induce hepatotoxicity [23]. To ensure that increased liver injury in Has3-/- mice was not due to differences in $\mathrm{CCl}_{4}$ bioactivation, we measured cytochrome P450 2E1 (CYP2E1) protein (Fig. 3a, b) and activity (Fig. 3c) levels; there was no difference in these parameters between genotypes. Surprisingly, in contrast to the pathogenic role HAS3 plays in injury in other animal models of human disease, our data suggest that HAS3 plays a protective role in the liver after acute $\mathrm{CCl}_{4}$ exposure.

\section{Hepatic inflammation after acute $\mathrm{CCl}_{4}$ exposure in wild-type and Has3-/- mice}

We next investigated the impact HAS3-deficiency on hepatic inflammation. While inflammatory markers increased in the livers from both strains of mice after $\mathrm{CCl}_{4}$ exposure, these markers tended to be greater in the Has3-/- mice compared to the wild-type mice. Specifically, using realtime PCR, we found hepatic Ccl2, Cxcl1, and Cxcl10 were increased in the Has3-/- mice (Fig. 4a-c). None of these transcripts were different between genotypes at other time points (data not shown). Consistently, using a cytokine protein array, we found that plasma CCL2, CXCL1, and CXCL10 chemokine proteins were also increased in the Has3-/- mice (Fig. 4d-f). High Cd11b expression is associated with pro-inflammatory, infiltrating macrophages after acute liver injury [24]. While precise evaluation of the inflammatory infiltrate is outside the goal of this manuscript, we were able to detect an increase in hepatic accumulation of $C d 11 b$ transcripts in Has3-/mice which approached significance (Additional file 1).

Effect of Has3-deficiency on hepatic stellate cell activation and fibrosis after acute and chronic $\mathrm{CCl}_{4}$

Although acute $\mathrm{CCl}_{4}$ exposure does not cause fibrosis, it does induce activation of hepatic stellate cells (HSC), cells integral to hepatic wound healing through, in part, matrix remodeling and matrix synthesis. Because liver 

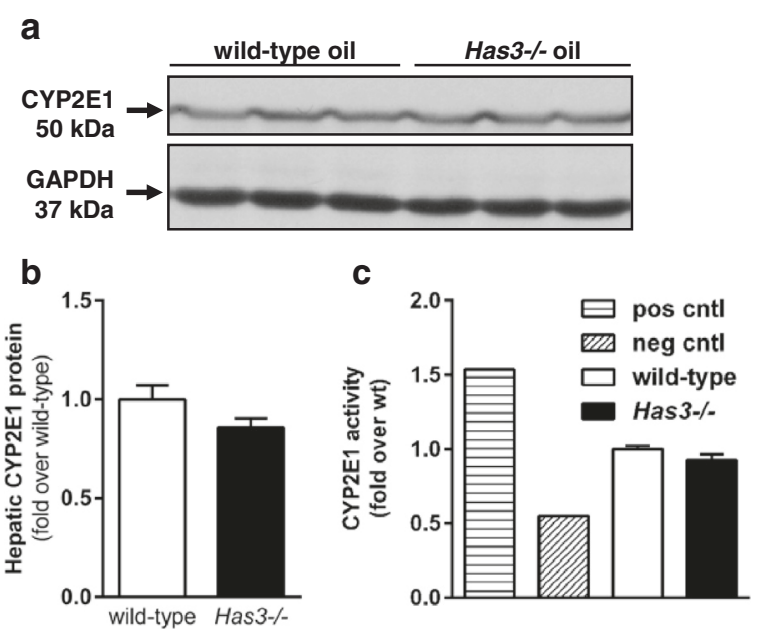

Fig. 3 CYP2E1 content and activity in wild-type and Has3-/- mice. a Representative CYP2E1 immunoblot using samples from olive oil-treated wild-type and Has3-/- mice. GAPDH was used as a loading control. b Semi-quantification of hepatic CYP2E1 content after normalization to GAPDH. Data are expressed as fold change over wild-type mice ( $n=6$ each genotype). c Hepatic CYP2E1 activity assay in microsomes isolated from the wild-type and Has3-/- mice at baseline (before $\mathrm{CCl}_{4}$ exposure) ( $n=6$ mice per experimental group). The data are expressed as fold change over wild-type. Pos cntl, microsomes prepared from a single mouse fed an ethanol-containing diet for 5 weeks (ethanol is known to increase CYP2E1). Neg cntl, microsomes prepared from a single mouse exposed to $\mathrm{CCl}_{4}$ and euthanized $24 \mathrm{~h}$ later $\left(\mathrm{CCl}_{4}\right.$ consumptively depletes CYP2E1)

injury and inflammation were increased in the Has3-/mice after acute $\mathrm{CCl}_{4}$ exposure, we predicted that the wound healing response would also be increased. After acute $\mathrm{CCl}_{4}$ exposure, markers associated with HSC activation were increased in both mouse strains. However, these markers were greater in the livers from the Has3-/- mice $48 \mathrm{~h}$ after $\mathrm{CCl}_{4}$. Specifically, using real-time PCR, we found that hepatic pro-fibrotic growth factor transcript accumulation (transforming growth factor ( $T g f) \beta 1$ and connective tissue growth factor $(C t g f))$ were increased in the livers from the Has3-/- mice (Fig. 5a, b). Consistent with a role for these mediators in HSC activation, hepatic $\alpha$ smooth muscle actin ( $\alpha$ SMA, Acta2), type I collagen (Col1a1, Col1a2), and heat shock protein 47 (Serpinh1), the collagen-specific chaperone, were increased $48 \mathrm{~h}$ after $\mathrm{CCl}_{4}$ exposure. These transcripts were each increased further in the HAS3-deficient mice (Fig. 5c-f). Collectively, these data suggest that increased injury and inflammation in the Has3-/- mice induces a more robust wound healing response in the liver after acute $\mathrm{CCl}_{4}$.

To evaluate the impact HAS3-deficiency had on frank fibrosis, we administered $\mathrm{CCl}_{4}$ twice per week for 5 weeks to wild-type and Has3-/- mice. Real-time PCR data revealed no difference in actin alpha 2 , smooth muscle, aorta (Acta2) ( $\alpha \mathrm{SMA})$ transcripts after chronic $\mathrm{CCl}_{4}$ exposure (Fig. 6a). Col1a1 and Col1a2 transcript accumulation was also induced in both strains and was increased in the Has3-/- mice (Fig. 6b, c). Interestingly, and in contrast to $\mathrm{HA}$ levels after acute $\mathrm{CCl}_{4}, \mathrm{HA}$ levels were not reduced in the Has3-/- mice at baseline or $72 \mathrm{~h}$ after $\mathrm{CCl}_{4}$. Although not significant, a trend to an increase in plasma HA was observed in the Has3-/- mice after chronic $\mathrm{CCl}_{4}$ exposure (Fig. 6d). Has enzyme transcript levels did not account for this difference in plasma HA concentration (Fig. 6e). To evaluate actual hepatic content of ECM proteins, liver sections from each mouse were stained using Sirius red. Semi-quantification of Sirius red staining demonstrated established fibrosis in both strains of mice (Fig. 7a). However, after morphometry to quantify Sirius red-positive staining, there was no difference in ECM accumulation between genotypes (Fig. 7b). Consistently, collagen content, measured biochemically, was not different between the wild-type and Has3-/- mice (Fig. 7c).

\section{Evaluation of matrix remodeling in wild-type and Has3-/- mice}

Faced with an apparent paradox (i.e., increased liver injury, inflammation, and fibrotic transcript accumulation after acute liver injury but equivalent hepatic ECM content after chronic liver injury), we hypothesized that the Has3-/mice had an increased ability to remodel their hepatic ECM after chronic $\mathrm{CCl}_{4}$ exposure; increased ability to degrade the ECM could be responsible for the equivalent ECM content in livers from both mouse strains. Using real-time PCR, we evaluated hepatic accumulation of matrix metalloproteinase $(M m p)$ and tissue inhibitor of matrix metalloproteinase (Timp) transcripts after chronic $\mathrm{CCl}_{4}$. While there was no difference in $M m p 2, M m p 9$, or Timp1 (Fig. 8a-c), Mmp13 transcripts were increased in the livers from the Has3-/- mice; there was no difference between baseline $M m p 13$ transcript levels between genotypes (Fig. 8d). We used immunoblotting to further evaluate hepatic MMP13. We found that, under basal conditions, the livers from the Has3-/- and wild-type mice had a substantial active form of the MMP13 enzyme; the ratio between active and pro MMP13 was not different between genotypes (Fig. 8e, f). This likely reflects normal matrix remodeling. However, after chronic $\mathrm{CCl}_{4}$ exposure, only the Has3-/- mice had an increase in the ratio of active MMP13 to pro MMP13. To determine if these changes in hepatic MMP13 resulted in increased matrix remodeling, we performed in situ zymography, in vitro, using dye-quenched gelatin as a substrate [25]. In this technique, location, area, and intensity of a matrixdegrading activity is visualized by the presence of green fluorescence. This technique revealed matrix metabolism in the fibrotic septae in the liver sections from the wildtype and HAS3-deficient mice (Fig. 9a). However, the intensity and total area of fluorescence (i.e., matrix remodeling) was threefold greater in the Has3-/- mice 

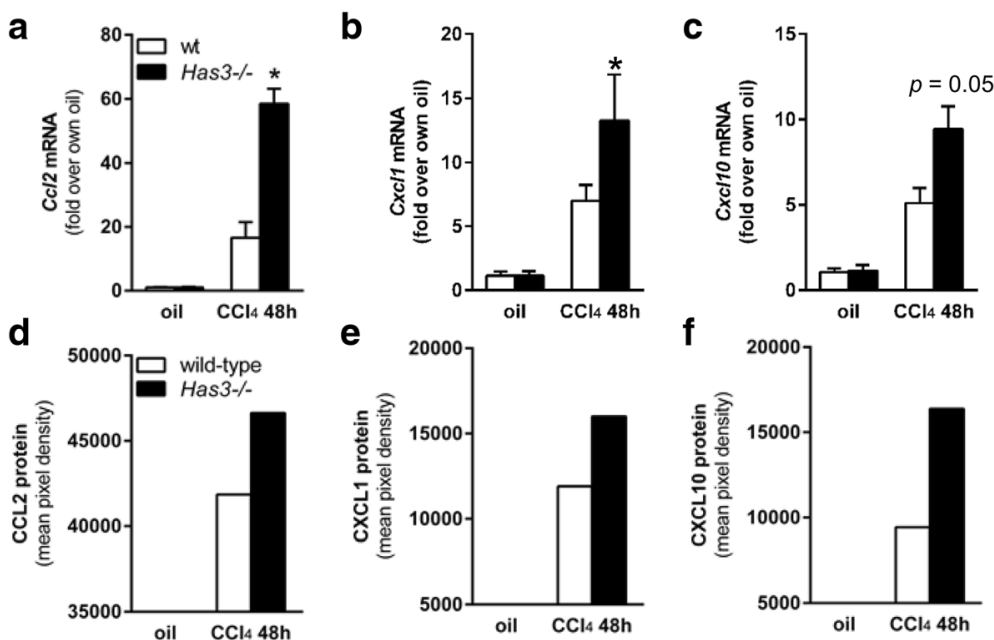

Fig. 4 Hepatic and plasma chemokine content in wild-type and Has3-/- mice. Forty-eight hours after $\mathrm{CCl}_{4}$ exposure, the mice were euthanized and the livers were collected to determine the relative amounts of $\mathbf{a} C \mathrm{C} 2, \mathbf{b} \mathrm{C} x \mathrm{Cl}$, and $\mathbf{c} \mathrm{Cxcl10}$ transcripts in both genotypes. Here and throughout the manuscript, data were calculated using the $2^{-\Delta \Delta \mathrm{Ct}}$ method after normalization to $18 \mathrm{~S}$ and are expressed as fold change over each genotype's own baseline (oil). Plasma isolated from blood collected at the same time points was used to determine the relative amounts of CCL2 (d), CXCL1 (e), and CXCL10 (f) peptides using a protein array. For this assay, plasma samples were pooled per experimental group ( $n=6-8$ mice). The bar graphs in $\mathbf{d}-\mathbf{f}$ were created after semi-quantification of chemokine spot density from the array after densitometric analysis (spots not shown). ${ }^{*} P<0.05$ compared between genotypes at the same time point

(Fig. 9b, c). Importantly, when incubated with a MMP13specific inhibitor, matrix remodeling was reduced in the livers from the Has3-/- mice; the inhibitor did not suppress matrix metabolism in the livers from the wild-type mice. Therefore, even though the Has3-/- mice exhibited worse liver injury, inflammation and pro-fibrotic gene expression after acute $\mathrm{CCl}_{4}$, this did not precipitate increased fibrosis after chronic $\mathrm{CCl}_{4}$ exposure. Instead, the Has3-/- mice exhibited an increased capacity to remodel the hepatic ECM during fibrosis limiting fibrotic disease.

\section{Discussion}

In this manuscript, we provide the first evidence to suggest that HAS3, and presumably HA produced by HAS3, plays differential roles after acute and chronic liver injury. Specifically, HAS3 protects the liver after acute liver injury by dampening hepatic inflammation. Our data suggest that this protective effect may be due to the total amount and relative proportions of critical molecular weight HA pools. In addition, the HAS-deficient mice exhibited an enhanced ability to remodel the ECM after chronic $\mathrm{CCl}_{4}$, and this was dependent on MMP13. The presence of more, lower molecular weight HA fragments in Has3-/mice may have driven the enhanced MMP13 response as shown previously [26]. Enhanced matrix remodeling prevented the increase in fibrosis we predicted based on hepatic fibrotic gene transcript accumulation in Has3-/mice after acute and chronic $\mathrm{CCl}_{4}$ exposure. Therefore, HAS3-mediated HA production is pathologic in chronic liver injury. This dichotomous relationship between the roles for HAS3 after acute or chronic liver injury likely reflects important differences between where in the liver wound healing continuum one looks.

Despite a well-appreciated role for plasma $\mathrm{HA}$ as a hepatic function biomarker [18, 27, 28], few studies have explored the role HA plays in pathogenesis or resolution of liver disease. It is known that HSC can synthesize HA and do so in response to partial hepatectomy, a surgical model of liver regeneration [29]. In addition, treating mice with HMW-HA $(780,900$, or $1200 \mathrm{kDa})$, but not LMW-HA (250 and $470 \mathrm{kDa}$ ), can prevent T cell mediated liver injury (concanavalin A and galactosamine/lipopolysaccharide models), and this occurs through a reduction in pro-inflammatory cytokines, including tumor necrosis factor $\alpha$, interferon gamma, macrophage inflammatory protein 2 (MIP2), and interleukin 4 [30]. Administration of human umbilical vein HA (HMW-HA) also exerts some protection against $\mathrm{CCl}_{4}$-induced liver injury, lipid peroxidation, and fibrosis in rats when used in combination with chondroitin sulfate, but not when either molecule was used alone [31]. Collectively, these studies, as well as our study, suggest that HA can exhibit a protective effect in animal models of acute liver disease.

While no one has yet explored the effect of HAS enzyme deficiency in animal models of liver injury, investigators have evaluated the impact HAS3 deficiency has in other animal models of human disease; these studies largely support a pathogenic role for HAS3. For example, 

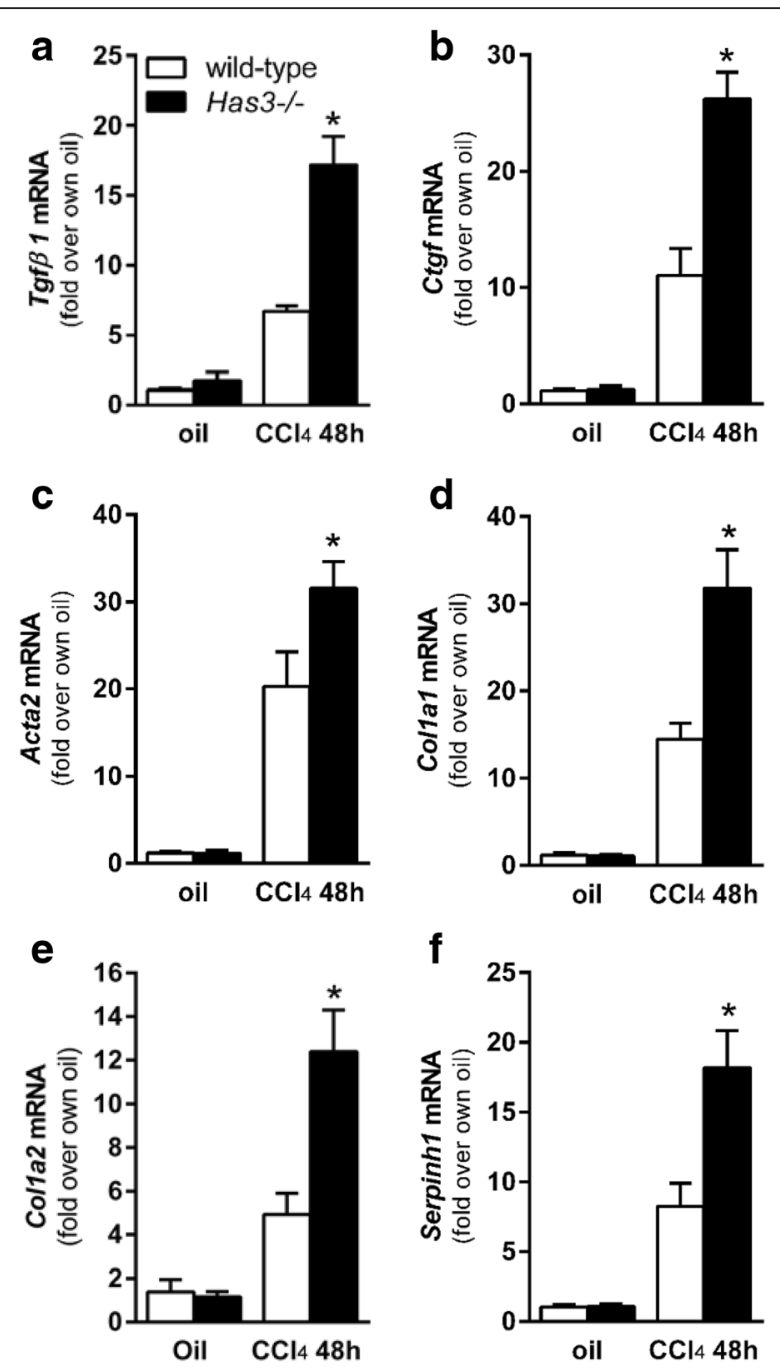

Fig. 5 Hepatic fibrotic marker transcript accumulation after acute $\mathrm{CCl}_{4}$ exposure. The mice were exposed to $\mathrm{CCl}_{4}$ and euthanized $48 \mathrm{~h}$ later. Control animals received an olive oil (oil) injection. Hepatic a. Tgf $\beta$ 1, b Ctgf, c Acta2, d Col1a1, e Col1a2, and f Serpinh1 were measured using real-time PCR. The data are expressed as fold change over each strain's olive oil-treated control after normalizing for input CDNA using $18 \mathrm{~S}$ ( $n=6-8$ mice per experimental group). ${ }^{*} P<0.05$ compared between genotypes at the same time point

in the lung, Bai et al. demonstrated that high tidal volume, ventilator-induced pulmonary MIP2 production, and neutrophil infiltration are robust in wild-type mice, but suppressed in mice deficient in HAS3 [14]. The increase in inflammation in wild-type mice is associated with increased pulmonary accumulation of HA favoring lower molecular weight species $(178-370 \mathrm{kDa})$; this was not observed in Has3-/- mice. Likewise, Kessler et al. demonstrated that HAS3-null mice are protected from dextran sodium sulfate (DSS)-induced colitis when compared to wild-type mice [16]. In the absence of HAS3, HA deposition and leukocyte infiltration are profoundly attenuated and associated with reduced weight loss and
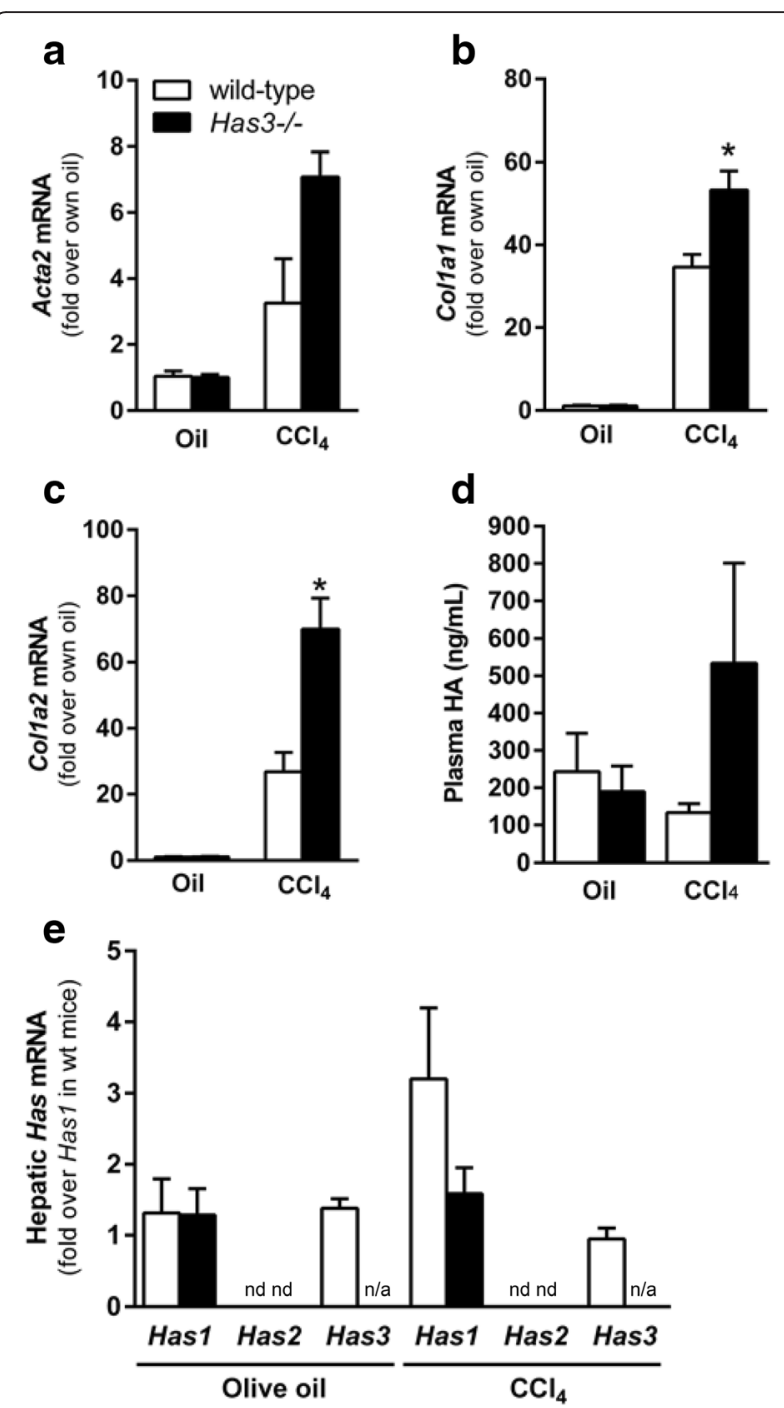

Fig. 6 Hepatic fibrotic marker transcript accumulation and plasma $\mathrm{HA}$ levels after chronic $\mathrm{CCl}_{4}$ exposure. The mice were exposed to $\mathrm{CCl}_{4}$ for 5 weeks, twice per week, and were euthanized $72 \mathrm{~h}$ after the final $\mathrm{CCl}_{4}$ exposure. Control animals received olive oil (oil) injections. Hepatic a Acta2, b Col1a1, and c Col1a2 transcript accumulation was determined using real-time PCR. The data are expressed as fold change over each strain's olive oil-treated control after normalization to 18S. d HA concentration was determined using an HA ELISA-like assay (see the "Methods" section for details). e Hepatic Has enzyme transcript levels in wild-type and Has3-/- mice. Data were normalized to Has7 levels in wild-type mice at baseline. $N=5-6$ mice per experimental group. nd not detected, i.e., transcripts were below the level of detection, n/a not applicable. ${ }^{*} P<0.05$ compared between genotypes

pro-inflammatory cytokine production after DSS exposure. In both of these studies, and in contrast to our study, HAS3 drives tissue inflammation.

The specific mechanisms behind pathogenic function of HAS3 in the lung and in the gut remain controversial. One hypothesis is that because HAS3 can make smaller HA polymers compared to HAS1 and HAS2 [8], perhaps HAS3-synthesized HA is small enough to 

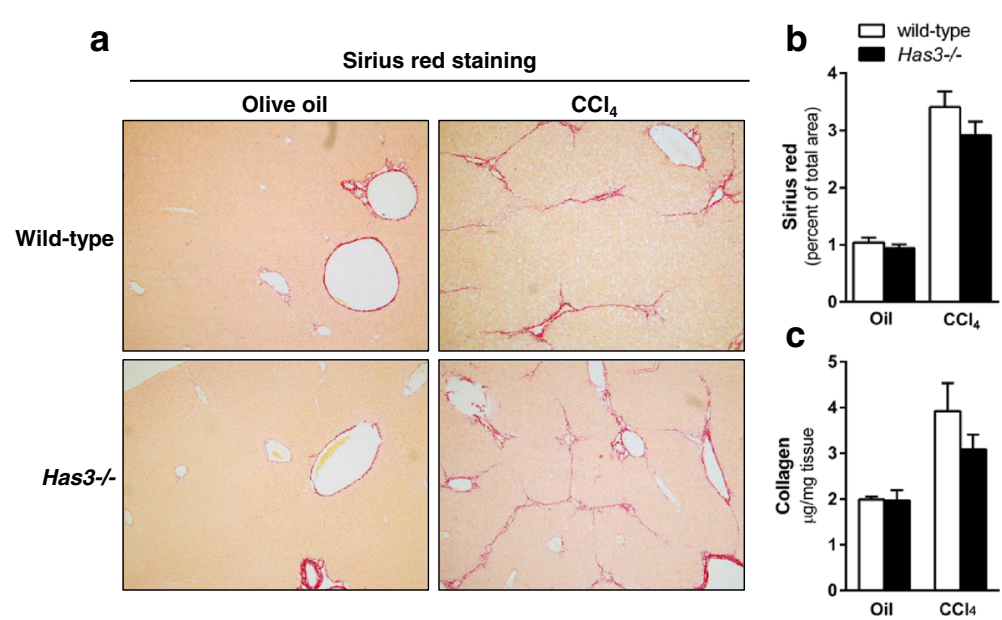

Fig. 7 Liver fibrosis in wild-type and Has3-/- mice after chronic $\mathrm{CCl}_{4}$ exposure. The mice were exposed to $\mathrm{CCl}_{4}$ for 5 weeks, twice per week, and were euthanized $72 \mathrm{~h}$ after the final $\mathrm{CCl}_{4}$ exposure. Control animals received olive oil (oil) injections. a Sirius red was used to localize extracellular matrix accumulation in the livers from the control and $\mathrm{CCl}_{4}$-treated mice (red bands around vascular units and extending from and connecting neighboring central veins, $\times 100$ magnification). b Semi-quantification of Sirius red staining expressed as a percent of total tissue area. Similar quantification of Sirius red staining intensity was also performed, and no differences were observed between groups (data not shown). c Hepatic hydroxyproline concentration was determined using a biochemical assay from which approximate collagen content was calculated (see the "Methods" for further details). $N=5-6$ mice per experimental group

be pro-inflammatory on its own. Conversely, perhaps LMW-HA synthesized by HAS3 is not directly proinflammatory but because it is smaller initially, it is more rapidly degraded into HA species which are proinflammatory. Another possible explanation is that HAS enzymes are differentially expressed in various tissues, cell types, or in response to different stimuli. Therefore, loss of one enzyme could profoundly influence the nature of the inflammatory response to injury in a tissue or celltype-specific fashion [7]. Therefore HAS3's differential effect, pathologic vs protective depending on the animal model or in acute vs chronic disease, should be
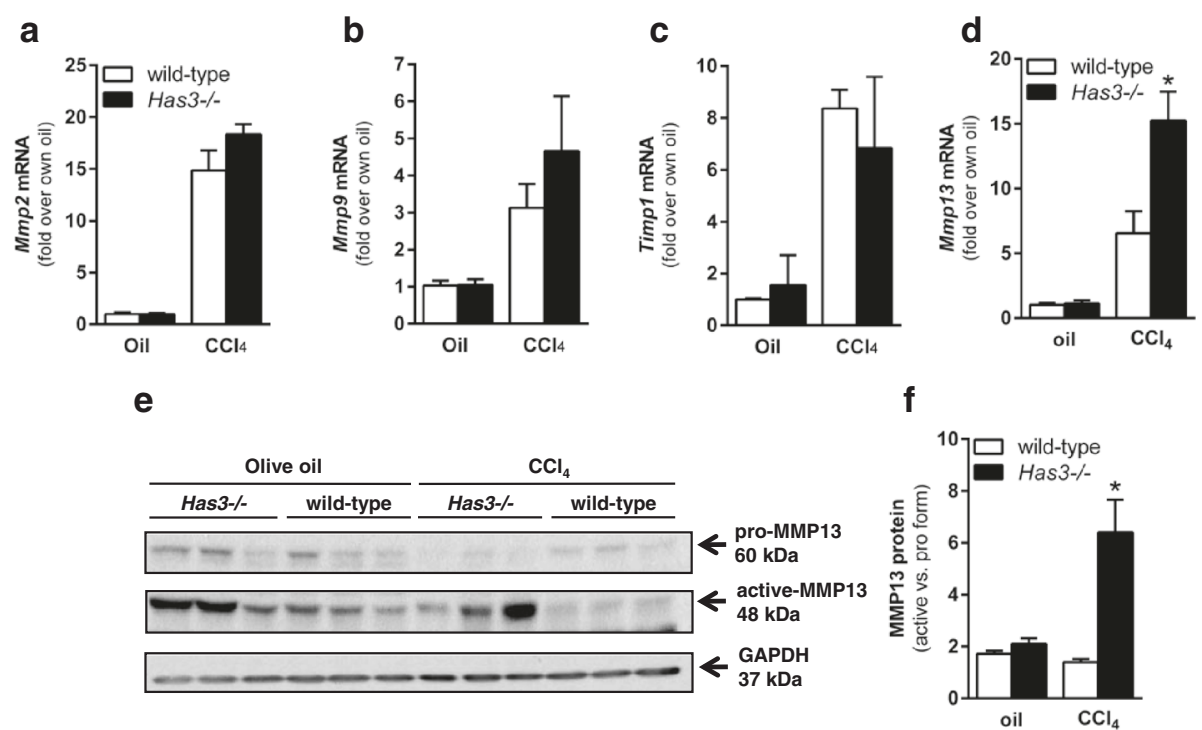

Fig. 8 Hepatic Mmp and Timp content in the livers from wild-type and Has3-/- mice. The mice were exposed to $\mathrm{CCl}_{4}$ for 5 weeks, twice per week, then were euthanized $72 \mathrm{~h}$ after the final $\mathrm{CCl}_{4}$ exposure. Control animals received olive oil (oil) injections. Hepatic a Mmp2, b Mmp9, c Timp1 and $\mathbf{d}$ Mmp13 transcript accumulation was evaluated using real-time PCR. Data are expressed as fold change over each strain's baseline (oil) after normalization to 18S. e Representative immunoblot of hepatic pro and active MMP13 protein. GAPDH is used to demonstrate equal loading. $\mathbf{f}$ Semi-quantification MMP13 band densities expressed as relative amount of active MMP13 relative to pro MMP13. $N=5-6$ mice per experimental group. ${ }^{*} P<0.05$ compared between genotypes 


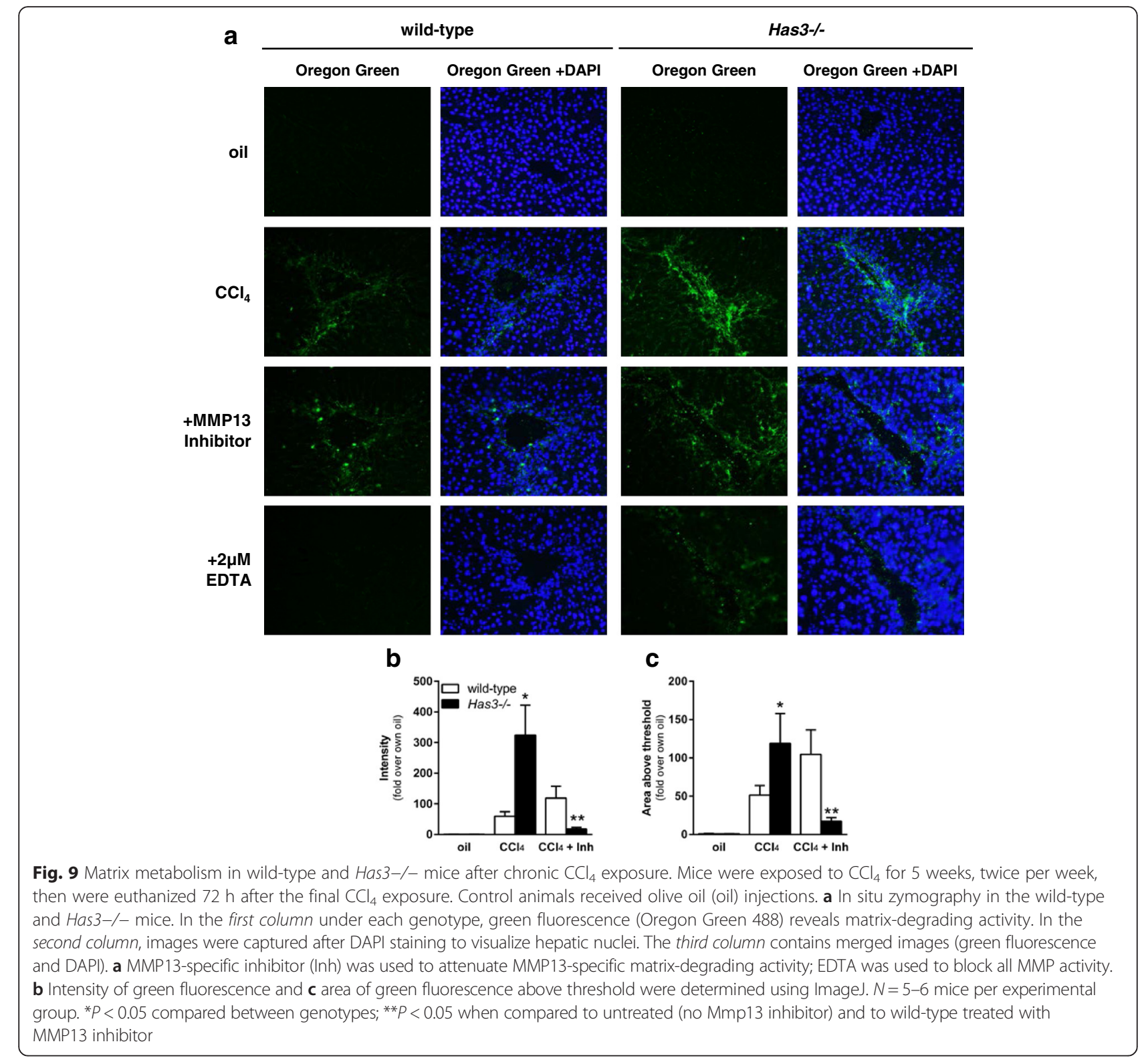

explored further by evaluating in which cell types HAS3 is expressed as well as by elucidating the local production and turnover of HA after tissue injury. Indeed, in the DSS-induced colitis model, HAS3 expression is predominantly localized to the endothelial cells found in gut microvessels where it produces a leukocyteadhesive HA and contributes to inflammation [32]. Further exploration of cell-type-specific hepatic HAS enzyme expression, hepatic HA accumulation, and hepatic HA molecular weight distribution during liver disease pathogenesis, progression, or resolution is required to understand the differences between our study and the other studies discussed above.

In this study, we observed increases in hepatic mRNA and plasma protein levels for chemokines and CD11b, a marker associated with monocyte recruitment to the liver [24] associated with tissue inflammation. These chemokines can attract a number of cells involved in innate an adaptive immune responses to tissue injury including monocytes/ macrophages (CCL2, CXCL10), neutrophils (CXCL1), natural killer cells (CXCL10), dendritic cells (CCL2, CXCL12), and $\mathrm{T}$ cells (CCL2, CXCL10). We believe that chemokine production is at a critical nexus between the promotion of liver injury and, paradoxically, resolution of fibrosis. Indeed, while CYP2E1-mediated bioactivation is required for $\mathrm{CCl}_{4}$ 's hepatotoxic effects [33], macrophages and macrophage recruitment also contribute to liver injury in this model. Specifically, if macrophages are depleted using gadolinium chloride, liver injury after $\mathrm{CCl}_{4}$ exposure is reduced [34]. Similarly, the mice deficient in CCL2 or the 
CCL2 receptor, CCR2, exhibit reduced plasma ALT activities, intrahepatic inflammatory cytokine expression, and macrophage recruitment after $\mathrm{CCl}_{4}$ exposure [35, 36]. Therefore, increased inflammatory macrophage recruitment in response to increased chemokine production in Has3-/- mice could contribute to increased injury after $\mathrm{CCl}_{4}$ exposure.

In addition to exacerbating liver injury and inflammation, hepatic macrophages and macrophage recruitment are also critical determinants of fibrosis resolution. For example, depleting macrophages with diphtheria toxin using a CD11b-diphtheria toxin receptor transgenic mouse attenuates matrix degradation in fibrotic liver [37]. Likewise, $\mathrm{CCl}_{4}$-induced fibrosis resolution is reduced when macrophage recruitment is prevented in CCR2-deficient mice [36]. Therefore, enhanced chemokine production in response to acute $\mathrm{CCl}_{4}$ could facilitate better fibrosis resolution by recruiting more macrophages to the injured liver.

As described by others, MMP13 is critical for resolution of liver fibrosis in mice and is associated with a resolutionassociated macrophage population called scar-associated macrophages (SAMs) [38]. MMP13 degrades fibrillar collagen and also exhibits gelatinase activity [39, 40]. Consistently, in mice with reduced hepatic SAMs, fibrosis resolution after cessation of $\mathrm{CCl}_{4}$ exposure is delayed and associated with reduced hepatic expression of Mmp13 mRNA and active MMP13 enzyme [36, 41]. It is important to note, however, that global deletion of MMP13 reduces fibrosis after bile duct ligation (BDL). Uchinami et al. demonstrated that reduced liver injury and inflammation in MMP13-deficient mice was responsible for the diminished fibrotic response after BDL [42]. This suggests that the role MMP13 plays in different points in the wound healing response may be critical to its overall impact on fibrosis. In this study, we found increased Mmp13 transcript accumulation, active form of MMP13 and MMP13 enzyme activity after chronic $\mathrm{CCl}_{4}$; we believe this contributed to the increased matrix remodeling in the Has3-/- mice. HA oligosaccharides are known inducers of MMP13 [26] It is tempting to speculate that increased HA levels found in the Has3-/- mice after chronic exposure to $\mathrm{CCl}_{4}$ may have contributed to the increase in MMP13 levels we found in this study. While beyond the scope of this manuscript, we are currently exploring macrophage phenotype in Has3-/- mice after chronic $\mathrm{CCl}_{4}$ and the response of macrophages to specific HA polymer sizes to more clearly understand the mechanism behind the observations made in this study.

\section{Conclusions}

We have demonstrated that HAS3, or HA synthesized by HAS3, is a critical determinant of the divergent outcomes observed after acute and chronic liver injury in response to $\mathrm{CCl}_{4}$. Importantly, our data suggest that $\mathrm{HA}$ plays two roles in the liver, one in which it attenuates liver injury and inflammation and one in which it exacerbates fibrosis. Further work is required to understand this apparently dichotomous relationship between HA and acute vs chronic liver injury and leverage that information for the development of HA-targeted therapeutics in liver disease.

\section{Methods \\ Reagents}

Primary antibodies used include the following: CYP2E1 (Abcam, Cambridge, MA), MMP13 (clone LIPCO-IID1, Abcam), and glyceraldehyde 3-phosphate dehydrogenase (GAPDH) (Cell Signaling, Clone 14C10, Beverly, MA). A horseradish peroxidase (HRP)-conjugated goat-anti-rabbit secondary antibody (Abcam) was used for the primary antibodies listed above. Olive oil and carbon tetrachloride were purchased from Sigma-Aldrich (St. Louis, MO), Buprenex analgesic (buprenorphine $\mathrm{HCl}$ ) was manufactured by Reckitt Benckiser Healthcare (UK, Ltd, Hull England) and distributed by Reckitt Benckiser Pharmaceuticals, Inc. (Richmond, VA). Anesthetics used were from the following sources: ketamine (Akorn, Inc, Decator, IL), xylazine (KetaVed, VedCO, Inc., St. Joseph, MO), and acepromazine (VedCO, Inc.). Pyrimidine-4,6-dicarboxylic acid, bis(4-fluoro-3-methyl-benzylamide) was used as a selective MMP13 inhibitor (EMD Millipore/Calbiochem, Billerica, MA, catalog number \#444283).

\section{Animal care}

The animals were treated humanely and in accordance to protocols approved by the University of Kansas Medical Center's (KUMC) Institutional Animal Care and Use Committee (IACUC). The mice were housed in ventilated cages on a 10/14-h light/dark cycle with access to standard mouse chow and water ad libitum. The Has3-/- mice were generated by Bai et al. through gene targeting, eliminating the catalytic site of the HAS3 enzyme [14]. Male Has3-/- mice (C57BL/6) background, confirmed by NNT genotyping) were bred at KUMC. Age-matched, wild-type (C57BL/6 J), male mice (acute $\mathrm{CCl}_{4}$ studies, see below) or female and male mice (chronic $\mathrm{CCl}_{4}$ studies) were purchased from Jackson Labs (Bar Harbor, ME) and used within 2 weeks of arrival at KUMC. There were no differences in disease pathogenesis parameters between male and female mice in chronic $\mathrm{CCl}_{4}$ studies. NNT genotyping confirmed that the Has3-/- mice and C57BL/6J mice were on the same $(\mathrm{BL} / 6 \mathrm{~J})$ genetic background.

\section{Carbon tetrachloride exposure, tissue collection, and storage}

In acute $\mathrm{CCl}_{4}$ studies, the mice were given a single intraperitoneal (i.p.) injection of $\mathrm{CCl}_{4}$ at a concentration of $0.4 \mathrm{mg} / \mathrm{g}$ body weight diluted 1:3 in olive oil. In the chronic 
studies, the mice were given two $\mathrm{CCl}_{4}$ injections per week for 5 weeks ramping up from $0.1 \mathrm{mg} / \mathrm{g} \mathrm{BW}$ (one injection) to $0.2 \mathrm{mg} / \mathrm{g} \mathrm{BW}$ (one injection) to $0.4 \mathrm{mg} / \mathrm{g} \mathrm{BW}$ (8 eight injections). Subcutaneous administration of an analgesic (buprenorphine) preceded each $\mathrm{CCl}_{4}$ injection by $10 \mathrm{~min}$ as done previously [43] and on recommendation by the KUMC IACUC. The control mice received analgesic and olive oil injection(s). Twenty-four, 48, 72, or $96 \mathrm{~h}$ (acute) or $72 \mathrm{~h}$ (chronic) post $\mathrm{CCl}_{4}$, the mice were anesthetized using a cocktail of ketamine $(200 \mathrm{mg} / \mathrm{kg})$, xylazine $(40 \mathrm{mg} / \mathrm{kg})$, and acepromazine $(20 \mathrm{mg} / \mathrm{kg})$. Blood was collected from the inferior vena cava into EDTA and aprotinin-containing tubes and placed on ice. After the blood was collected, the diaphragm, superior vena cava, and aorta were cut euthanizing the mouse. After euthanasia, a hepatectomy was performed. The liver was divided into several pieces while on an ice-chilled piece of glass: the small half of the median lobe was cut into three pieces and placed into 2-mL tubes with $1.5 \mathrm{~mL}$ of RNAlater (Life Technologies, Grand Island, $\mathrm{NY}$ ) stored at room temperature for $5 \mathrm{~min}$, at $4{ }^{\circ} \mathrm{C}$ for $18 \mathrm{~h}$ and then transferred to $-20^{\circ} \mathrm{C}$ until use. A portion of the large half of the median lobe was embedded in Optimal Cutting Temperature (OCT) medium, incubated on a bed of frozen isopentane until the OCT was opaque and then stored at $-80{ }^{\circ} \mathrm{C}$. The largest lobe of the liver (left lobe) was cut into several slices, and some of which were used for Western blot analysis (snap frozen in liquid nitrogen, stored at $-80{ }^{\circ} \mathrm{C}$ ) or fixed in formalin and later embedded in paraffin for histological analysis. The right lobe was snap frozen in liquid nitrogen and then stored at $-80{ }^{\circ} \mathrm{C}$ for triglyceride quantification. All remaining liver tissue was snap frozen and archived at $-80{ }^{\circ} \mathrm{C}$; CYP2E1 activity assays were performed using pieces from the left lobe. The blood was centrifuged at $10,000 \times g$ for $3.5 \mathrm{~min}$. Plasma was separated into two aliquots and frozen at $-80{ }^{\circ} \mathrm{C}$ until use.

\section{Liver injury and hepatic triglyceride content determination} Plasma alanine aminotransferase (ALT) activity was determined using a commercially available enzymatic assay (Sekisui Diagnostics, Exton, PA) according to the manufacturer's instructions. Activity was calculated using the extinction coefficient method. For triglyceride measurement, the livers were digested with $3 \mathrm{M} \mathrm{KOH}$ in $65 \%$ ethanol for $1 \mathrm{~h}$ at $70{ }^{\circ} \mathrm{C}$ and vortexed every $20 \mathrm{~min}$ to aid in tissue disruption. Twenty-four hours later, samples were diluted 1:5 in $2 \mathrm{M}$ tris $\mathrm{pH} 7.5,10 \mu \mathrm{L}$ was added to triglyceride GPO reagent (Trinder method), and absorbances were read at $500 \mathrm{~nm}$. A standard curve created using a GPO standard was used to calculate total hepatic triglyceride content (Pointe Scientific, Canton, MI).

\section{Histological analysis}

Formalin-fixed, paraffin-embedded sections were cut $(5 \mu \mathrm{M})$ and stained with hematoxylin and eosin. Micrographs were taken at $\times 200$ magnification using an Olympus BX51 microscope fitted with an Olympus DP71 camera (Olympus, Waltham, MA). DP Controller software was used to acquire images (Olympus, Waltham, MA). Three nonoverlapping images per liver section were acquired and viewed by a blinded individual (MFO). Assessments were made on a scale from 0 to $4+$ for the following parameters: cellular infiltrate, steatosis, necrosis, and hemorrhage.

\section{Immunoblotting}

Liver lysates were prepared as described [43], and samples were resolved on $10 \%$ SDS-PAGE gels. Proteins were transferred to PVDF membranes, blocked in $5 \%$ BSA, and then probed for proteins of interest overnight at $4{ }^{\circ} \mathrm{C}$ with agitation. HRP-conjugated secondary antibodies were used, and after incubation in an Enhanced Chemiluminescent substrate (GE Healthcare, Piscataway, NJ), luminescence was captured using radiographic film. Quantification of band density was achieved using ImageJ. Data were normalized to a housekeeping gene (GAPDH).

\section{CYP2E1 activity assay}

Liver microsomes were prepared by homogenizing 100 $150 \mathrm{mg}$ of frozen liver tissue in $1 \mathrm{~mL}$ of cold PBS with a loose fitting dounce homogenizer. After centrifugation at $9000 \times g$ for $15 \mathrm{~min}$, the fat layer was removed from the surface of the liquid and $10 \mathrm{~mL}$ of cold PBS was added and the homogenate was centrifuged at $105,000 \times \mathrm{g}$ for $1 \mathrm{~h}$ at $4{ }^{\circ} \mathrm{C}$. The pellet was resuspended in $0.15 \mathrm{M} \mathrm{KCl}$, and the total protein concentration was determined by BCA assay (Life Techologies/Pierce, Grand Island, NY). Four microliters of $10 \mathrm{mM}$ p-nitrophenol, and $10 \mu \mathrm{L}$ phosphate buffer (4 mL $1 \mathrm{M} \mathrm{K} 2 \mathrm{HPO} 4+1 \mathrm{~mL} 1 \mathrm{M} \mathrm{KH} 2 \mathrm{PO} 4 \mathrm{pH}$ 7.4) were added to $30 \mu \mathrm{g}$ of protein; water was added to bring the total volume to $100 \mu \mathrm{L}$. Ten microliters of freshly prepared NADPH $(10 \mathrm{nM})$ was then added, and the samples were incubated at $37^{\circ} \mathrm{C}$ in a water bath for $1 \mathrm{~h}$. Following incubation, $30 \mu \mathrm{L}$ of $20 \%$ trichloroacetic acid was added, and the samples were vortexed, then centrifuged 10,000 $\times g$ for $10 \mathrm{~min}$. One hundred microliters of supernatant was added to $10 \mu \mathrm{L} 10 \mathrm{~N} \mathrm{NaOH}$, and absorbance was determined at $510 \mathrm{~nm}$. CYP2E1 activity was calculated using the extinction coefficient of $9.53 \times 10^{5} \mathrm{M}^{-1} \mathrm{~cm}^{-1}$, normalized to protein concentration, and expressed as fold change over wild-type, oil-exposed (control) mice.

\section{RNA isolation, CDNA synthesis, and real-time PCR}

RNAlater-stabilized liver pieces (20-30 mg) were homogenized (FastPrep 24, MP Biomedicals, Solon, OH) in RLT buffer (RNeasy Mini Kit, Qiagen, Valencia, CA) with $10 \mu \mathrm{L}$ of $\beta$-mercaptoethanol per $\mathrm{mL}$ of RLT. RNA was then isolated using an RNeasy Mini Kit; $4 \mu \mathrm{g}$ of RNA was reverse transcribed into complementary DNA (cDNA) using a Retroscript kit (Life Technologies/Ambion, Grand 
Island, NY). SYBR green (BioRad Universal Super Mix,) was used for real-time PCR in a BioRad CFX384 real-time PCR machine, and results were calculated using $2^{-\Delta \Delta C t}$ method. Data were expressed as fold change over olive oil-treated mice within a genotype. Primers utilized in this study are found in Table 2; 18S was used as the housekeeping gene and did not differ between genotypes or time points after $\mathrm{CCl}_{4}$. Sequence sources are noted in the table, most of which were obtained from the PrimerBank (http://pga.mgh.harvard.edu/primerbank/) [44-46].

\section{Cytokine protein array}

Plasma cytokine protein content was measured using a Proteome Profiler: Mouse Cytokine Array Panel A (R\&D Systems) to evaluate inflammatory mediators present in pooled plasma samples from the mice exposed to $\mathrm{CCl}_{4}$ and euthanized $48 \mathrm{~h}$ later or in animals exposed to olive oil (control). In brief, pooled plasma samples ( $n=6-8$ individual mice per group) were applied to the provided membrane impregnated with capture antibodies. Streptavidin-HRPconjugated secondary antibodies were then applied, and chemiluminescent technology was used to detect proteins captured by the array. All arrays were done on the same day with the same exposure time. NIH ImageJ was used to semi-quantify pixel density of resultant cytokinepositive areas recorded using radiographic film.

\section{Size-selective HA fractionation and quantification}

Quantikine ELISA for HA (R\&D Systems, Minneapolis, $\mathrm{MN}$ ) was performed per manufacturer's instructions to determine the total HA content in plasma. Because HA is a carbohydrate, the ELISA did not utilize capture and detection antibodies. Instead, it utilized HA-binding proteins (HABP). The wells of a 96-well plate were coated with a capture HABP by the manufacturer. A biotinylated HABP was utilized as a detection reagent. We refer to this modified ELISA as an "ELISA-like assay" in this study. Determination of a size-specific HA fraction in plasma was done as described previously [47], with modification. Briefly, plasma was pooled $(n=4-8$ mice per time point) and digested 1:1 with 10× Proteinase K solution at $60{ }^{\circ} \mathrm{C}$ for $4 \mathrm{~h}$. Molecular weight cut-off columns (Centrisart, 100 and $300 \mathrm{kDa}$, Sartorius, Goettingen, Germany) were used to isolate HA with molecular weights less than $100 \mathrm{kDa}$, between 100 and $300 \mathrm{kDa}$ and greater than $300 \mathrm{kDa}$ from the wild-type and Has3-/- mice.

Sirius red staining, image acquisition and data collection Formalin-fixed, paraffin-embedded liver tissue sections were incubated at $60{ }^{\circ} \mathrm{C}$ for $20 \mathrm{~min}$, deparaffinized in SafeClear (xylene substitute, protocol II), and rehydrated in a graded series of ethanol. Slides were then immersed in $0.1 \%$ picrosirius red solution (Direct Red 80, in saturated picric acid) for $1 \mathrm{~h}$ at room temperature. Acidified water $(0.5 \%$ glacial acetic acid in water) was used to wash the slides three times for 5 min each. The slides were dehydrated in a reverse series of graded ethanol and fresh SafeClear solutions, mounted using Permount and glass coverslips and allowed to dry. An Olympus BX51 microscope and Olympus DP71 camera were used to

Table 2 Primers used for real-time PCR transcript analysis

\begin{tabular}{|c|c|c|c|c|c|}
\hline Gene name & Protein & Gen bank acc \# & Sequence source & Forward primer & Reverse primer \\
\hline Has1 & Has1 & NM_008215 & PrimerBank: 6680169a1 & GGCGAGCACTCACGATCATC & AGGAGTCCATAGCGATCTGAAG \\
\hline Has2 & Has2 & NM_008216 & Matrix Biol. 30(2):126-134, 2011 & GGTCCAAGTGCCTTACTGAAAC & TGTACAGCCACTCTCGGAAGTA \\
\hline Has3 & Has3 & NM_008217 & PrimerBank: 6680173a1 & GTGGGCACCAGTCTGTTTG & CCACTGAACGCGACCTCTG \\
\hline $\mathrm{CCl} 2$ & $\mathrm{CCL} 2 / \mathrm{MCP} 1$ & NM_011333 & Immunol. Cell Biol. 89:716, 2011 & AGGTCCCTGTCATGCTTCTG & TCTGGACCCATTCCTTCTTG \\
\hline Cxcl1 & CXCL1/GRO1/KC & NM_008176 & PrimerBank: 229577225c1 & ACTGCACCCAAACCGAAGTC & TGGGGACACCTITAAGCATCTT \\
\hline Cxcl10 & CXCL10/IP10 & NM_021274 & PrimerBank: 10946576a1 & CCAAGTGCTGCCGTCATITTC & GGCTCGCAGGGATGATTTCAA \\
\hline$C d 11 b$ & CD11b & NM_001082960 & PrimerBank: 132626288c3 & GGGAGGACAAAAACTGCCTCA & ACAACTAGGATCTTCGCAGCAT \\
\hline Tgfb 1 & TGF $\beta 1$ & NM_011577 & PrimerBank: 6755774b1 & AGCTGGTGAAACGGAAGCG & GCGAGCCTTAGTTTGGACAGG \\
\hline Ctgf & CTGF & NM_010217 & PrimerBank: 6753878a1 & GGGCCTCTTCTGCGATTTC & ATCCAGGCAAGTGCATTGGTA \\
\hline Acta2 & aSMA & NM_007392 & PrimerBank: 31982518b1 & CCCAGACATCAGGGAGTAATGG & TCTATCGGATACTTCAGCGTCA \\
\hline Collar & COL1A1 & NM_007742 & $\begin{array}{l}\text { World J. Gastroenterol. } \\
\text { 4(12):356, } 2012\end{array}$ & ATGTTCAGCTTTGTGGACCTC & CAGAAAGCACAGCACTCGC \\
\hline Colla2 & COL1A2 & NM_007743 & Am. J. Pathol. 176(6):2743, 2010 & GGTGAGCCTGGTCAAACGG & ACTGTGTCCTITCACGCCTIT \\
\hline Serpinh1 & HSP47 & NM_009825 & PrimerBank: 6753304a1 & GCCGAGGTGAAGAAACCCC & CATCGCCTGATATAGGCTGAAG \\
\hline Mmp2 & MMP2 & NM_008610 & PrimerBank: 47271505b1 & GATGTCGCCCCTAAAACAGAC & CAGCCATAGAAAGTGTTCAGGT \\
\hline Mmp9 & MMP9 & NM_013599 & PrimerBank: 31560795b2 & GGACCCGAAGCGGACATTG & GAAGGGATACCCGTCTCCGT \\
\hline Mmp13 & MMP13 & NM_008607 & PrimerBank: 291463259b1 & TGTITGCAGAGCACTACTTGAA & CAGTCACCTCTAAGCCAAAGAAA \\
\hline Timp1 & TIMP1 & NM_011593 & PrimerBank: 6755795a1 & GCAACTCGGACCTGGTCATAA & CGGCCCGTGATGAGAAACT \\
\hline
\end{tabular}


acquire images at $100 \times$ magnification using DP Controller software (Olympus, Waltham, MA). Five non-overlapping images per liver section were acquired. One liver section per mouse in each experimental group was photographed ( $n=5-6$ mice per group). ImageJ was used to quantify the area of positive staining above an arbitrary threshold which remained constant for all images.

\section{Hydroxyproline quantification and calculation of collagen content}

Collagen content was determined using the hydroxyproline assay as described by Reddy and Enwemeka [48]. Briefly, $10 \mathrm{mg}$ of liver tissue was digested in water and $12.1 \mathrm{~N} \mathrm{HCl}$ at $120{ }^{\circ} \mathrm{C}$ for $3 \mathrm{~h}$ using a dry bath incubator. The samples were vortexed every $30 \mathrm{~min}$ during this incubation period. The samples were centrifuged $10,000 \times g$ for $10 \mathrm{~min}$ after the incubation was complete. Ten microliters of the resulting supernatant was placed, in duplicate, into wells of a 96-well plate. Hydroxyproline standards $(0-1 \mu \mathrm{g} /$ well $)$ were also added to the plate, in duplicate. One hundred microliters of chloramine-T solution was added to each well and incubated for $25 \mathrm{~min}$ at room temperature, after which $100 \mu \mathrm{L}$ of Ehrlich's solution was added to each well and incubated further for $35 \mathrm{~min}$ at $60{ }^{\circ} \mathrm{C}$ in a dry heat incubator. Absorbances were measured at $550 \mathrm{~nm}$, and the concentration of hydroxyproline was calculated from the standard curve. Collagen content was estimated by dividing the hydroxyproline concentration by $12.5 \%$.

In situ zymography, image acquisition and data collection Frozen tissue sections $(7 \mu \mathrm{m})$ were taken from $-80{ }^{\circ} \mathrm{C}$ and immediately incubated with developing buffer $(100 \mathrm{mM}$ Tris, pH 7.4, $100 \mathrm{mM} \mathrm{NaCl}, 5 \mathrm{mM} \mathrm{CaCl} 2,0.05 \%$ Brij-35, $0.25 \mathrm{mM}$ PMSF) containing $0.1 \mathrm{mg} / \mathrm{mL}$ Oregon green 488, dye-quenched (DQ) gelatin (Life Technologies/Molecular Probes, Grand Island, NY). To a second set of sections, an MMP13 inhibitor (EMD Millipore/Calbiochem, Billerica, MA, catalog number \#444283) was added. This MMP13 inhibitor is also known as pyrimidine-4,6-dicarboxylic acid, bis-(4-fluoro-3-methyl-benzylamide), a non-zinc-chelating inhibitor of MMP13 [49]. It works by binding to the catalytic domain of the enzyme, preventing its activity. The slides were incubated in a humid chamber at $37{ }^{\circ} \mathrm{C}$ for $16-18 \mathrm{~h}$. After this incubation, 4',6-diamidino-2-phenylindole (DAPI) mounting medium was used as a nuclear counterstain and aqueous mounting medium, and then sealed using clear nail polish. An Olympus BX51 microscope with an Olympus BH2RFLT3 burner, Olympus DP71 camera, and DP Controller software were used to capture three non-overlapping images from each tissue section at 200x magnification. The exposure time was chosen to minimize autofluorescence in control liver sections and used for each subsequent image. ImageJ was used to quantify area and intensity of the fluorescent signal generated by matrix metabolism.

\section{Statistics}

Data were collected from several independent experiments. All results are presented as means \pm SEM or individual values alone. Statistical significance was defined as $P \leq 0.05$ and denoted with an asterisk $\left(^{*}\right)$. Student's $t$ test was used when comparing two data sets, and ANOVA was used when comparing more than two data sets and included a Tukey's adjustment for multiple comparisons. Analyses were performed using SAS (Cary, NC), GraphPad Prism 6 (La Jolla, CA), or Excel (Microsoft, Redmond, WA).

\section{Additional file}

Additional file 1: Hepatic C $111 b$ transcript analysis. Real-time PCR was utilized to determine hepatic accumulation of C $111 \mathrm{~b}$ transcripts in wild-type and Has3-/- mice at baseline (oil) or $48 \mathrm{~h}$ after $\mathrm{CCl}_{4}$ exposure. (PDF $23 \mathrm{~kb}$ )

\begin{abstract}
Abbreviations
Acta2: actin alpha 2, smooth muscle, aorta; ALT: alanine aminotransferase; $\mathrm{CCl}_{4}$ : carbon tetrachloride; Col1a1: collagen, type 1, alpha 1; Col1a2: collagen, type 1, alpha 2; Ctgf: connective tissue growth factor; CYP2E1: cytochrome P450 2E1; DAPI: 4',6-diamidino-2-phenylindole; DSS: dextran sodium sulfate; ECM: extracellular matrix; ELISA: enzyme-linked immunosorbent assay; HA: hyaluronan; HAS: hyaluronan synthase; HMW: high molecular weight; HSC: hepatic stellate cell; LMW: Iow molecular weight; MMP: matrix metalloproteinase; SAM: scar-associated macrophage; Serpinh1: serine (or cysteine) peptidase inhibitor, clade $\mathrm{H}$, member 1 ; $\operatorname{Tgf} \beta$ : transforming growth factor; Timp: tissue inhibitor of matrix metalloproteinase; aSMA: alpha smooth muscle actin.
\end{abstract}

\section{Competing interests}

The authors declare that they have no competing interests.

\section{Author contributions}

JMM, a graduate student, designed and performed the experiments, analyzed the data, and edited/revised the manuscript. LJ, another graduate student, performed the experiments. KTD, a laboratory technologist, bred and genotyped the mice required for the study. MFO, a board-certified pathologist, provided the histopathology analysis. MTP, the PI of the laboratory that performed this research, developed the conceptual framework for the study and supervised its execution. MTP designed the experiments, analyzed and interpreted the data, and wrote/edited/revised the manuscript. All authors approved the manuscript and agree to be accountable for all aspects contained within.

\section{Acknowledgements}

This work was supported by grants from the National Institutes of Health, National Center for Research Resources [P20 RR021940 to M.T.P.], National Institute of General Medical Sciences [P20 GM103549 to M.T.P.], National Institute of Environmental Health Sciences "Training Program in Environmental Toxicology" [T32 ES007079 to J.M.M.], and the National Institutes of Alcohol Abuse and Alcoholism [K99 AA017918A and R00 AA17918 to M.T.P.]. Special thanks to Drs. Vince Hascall, Carol de la Motte, and Sean Kessler from the Cleveland Clinic in Cleveland, $\mathrm{OH}$, who provided us with the hyaluronan synthase-deficient mice. Additional thanks to the University of Kansas Medical Center's Laboratory Animal Resource husbandry staff, veterinary technicians, veterinarians, Office of Animal Welfare, and Institutional Animal Care and Use Committee for the exceptional quality of our animal care program. 


\section{Author details}

'Department of Pharmacology, Toxicology and Therapeutics, University of Kansas Medical Center, Kansas City, KS 66160, USA. ²Department of Pathology, University of Kansas Medical Center, Kansas City, KS 66160, USA.

\section{Received: 21 December 2015 Accepted: 16 March 2016} Published online: 31 March 2016

\section{References}

1. Bataller R, Rombouts K, Altamirano J, Marra F. Fibrosis in alcoholic and nonalcoholic steatohepatitis. Best Pract Res Clin Gastroenterol. 2011;25:231-44.

2. Gunay-Aygun M. Liver and kidney disease in ciliopathies. Am J Med Genet C: Semin Med Genet. 2009;151C:296-306.

3. Gao B, Bataller R. Alcoholic liver disease: pathogenesis and new therapeutic targets. Gastroenterology. 2011;141:1572-85.

4. Ismail MH, Pinzani M. Reversal of hepatic fibrosis: pathophysiological basis of antifibrotic therapies. Hepat Med. 2011;3:69-80.

5. Schuppan D, Kim YO. Evolving therapies for liver fibrosis. J Clin Invest. 2013;123:1887-901.

6. Weissmann B, Meyer K, Sampson P, Linker A. Isolation of oligosaccharides enzymatically produced from hyaluronic acid. J Biol Chem. 1954;208:417-29.

7. Spicer AP, McDonald JA. Characterization and molecular evolution of vertebrate hyaluronan synthase gene family. J Biol Chem. 1998;273:1923-32.

8. Itano N, Sawai T, Yoshida M, Lenas P, Yamada Y, Imagawa M, Shinomura T, Hamaguchi M, Yoshida Y, Ohnuki Y. Three isoforms of mammalian hyaluronan synthases have distinct enzymatic properties. J Biol Chem. 1999; 274:25085-92

9. Jacobson A, Brinck J, Briskin MJ, Spicer AP, Heldin P. Expression of human hyaluronan synthases in response to external stimuli. Biochem J. 2000; 348(Pt 1):29-35.

10. Stern R, Asari AA, Sugahara KN. Hyaluronan fragments: an information-rich system. Eur J Cell Biol. 2006;85:699-715.

11. Jiang D, Liang J, Noble PW. Hyaluronan in tissue injury and repair. Annu Rev Cell Dev Biol. 2007;23:435-61.

12. Jiang D, Liang J, Noble PW. Hyaluronan as an immune regulator in human diseases. Physiol Rev. 2011;91:221-64.

13. Jiang D, Liang J, Fan J, Yu S, Chen S, Luo Y, Prestwich GD, Mascarenhas MM Garg HG, Quinn DA. Regulation of lung injury and repair by Toll-like receptors and hyaluronan. Nat Med. 2005;11:1173-9.

14. Bai KJ, Spicer AP, Mascarenhas MM, Yu L, Ochoa CD, Garg HG, Quinn DA. The role of hyaluronan synthase 3 in ventilator-induced lung injury. Am J Respir Crit Care Med. 2005;172:92-8.

15. Mascarenhas MM, Day RM, Ochoa CD, Choi WI, Yu L, Ouyang B, Garg HG, Hales CA, Quinn DA. Low molecular weight hyaluronan from stretched lung enhances interleukin-8 expression. Am J Respir Cell Mol Biol. 2004;30:51-60.

16. Kessler SP, Obery DR, de la Motte C. Hyaluronan synthase 3 null mice exhibit decreased intestinal inflammation and tissue damage in the DSSinduced colitis model. Intern J Cell Biol. 2015.

17. Nanji AA, Tahan SR, Khwaja S, Yacoub LK, Sadrzadeh SM. Elevated plasma levels of hyaluronic acid indicate endothelial cell dysfunction in the initial stages of alcoholic liver disease in the rat. J Hepatol. 1996;24:368-74.

18. Yagmur E, Koch A, Haumann M, Kramann R, Trautwein C, Tacke F. Hyaluronan serum concentrations are elevated in critically ill patients and associated with disease severity. Clin Biochem. 2012:45:82-7.

19. Gressner AM, Haarmann R. Regulation of hyaluronate synthesis in rat liver fat storing cell cultures by Kupffer cells. J Hepatol. 1988;7:310-8.

20. Gressner AM, Krull N, Bachem MG. Regulation of proteoglycan expression in fibrotic liver and cultured fat-storing cells. Pathol Res Pract. 1994;190:864-82.

21. Lindqvist U, Westerberg G, Bergstrom M, Torsteindottir I, Gustafson S, Sundin A, Loof L, Langstrom B. [11C]Hyaluronan uptake with positron emission tomography in liver disease. Eur J Clin Invest. 2000;30:600-7.

22. Constandinou C, Henderson N, Iredale JP. Modeling liver fibrosis in rodents. Methods Mol Med. 2005;117:237-50.

23. Weber LW, Boll M, Stampfl A. Hepatotoxicity and mechanism of action of haloalkanes: carbon tetrachloride as a toxicological model. Crit Rev Toxicol. 2003:33:105-36.

24. Holt MP, Cheng L, Ju C. Identification and characterization of infiltrating macrophages in acetaminophen-induced liver injury. J Leukoc Biol. 2008;84:1410-21.
25. Snoek-van Beurden PA, Von den Hoff JW. Zymographic techniques for the analysis of matrix metalloproteinases and their inhibitors. Biotechniques. 2005;38:73-83.

26. Fieber C, Baumann P, Vallon R, Termeer C, Simon JC, Hofmann M, Angel P, Herrlich P, Sleeman JP. Hyaluronan-oligosaccharide-induced transcription of metalloproteases. J Cell Sci. 2004;117:359-67.

27. Adams LA. Biomarkers of liver fibrosis. J Gastroenterol Hepatol. 2011; 26:802-9.

28. Lee CK, Perez-Atayde AR, Mitchell PD, Raza R, Afdhal NH, Jonas MM. Serum biomarkers and transient elastography as predictors of advanced liver fibrosis in a United States cohort: the Boston children's hospital experience. J Pediatr. 2013;163:1058-64. e1052.

29. Vrochides D, Papanikolaou V, Pertoft $H$, Antoniades AA, Heldin P. Biosynthesis and degradation of hyaluronan by nonparenchymal liver cells during liver regeneration. Hepatology. 1996:23:1650-5.

30. Nakamura K, Yokohama S, Yoneda M, Okamoto S, Tamaki Y, Ito T, Okada M, Aso K, Makino I. High, but not low, molecular weight hyaluronan prevents T-cell-mediated liver injury by reducing proinflammatory cytokines in mice. J Gastroenterol. 2004;39:346-54.

31. Campo GM, Avenoso A, Campo S, D'Ascola A, Ferlazzo AM, Calatroni A. The antioxidant and antifibrogenic effects of the glycosaminoglycans hyaluronic acid and chondroitin-4-sulphate in a subchronic rat model of carbon tetrachloride-induced liver fibrogenesis. Chem Biol Interact. 2004;148:125-38.

32. Kessler S, Rho H, West G, Fiocchi C, Drazba J, de la Motte C. Hyaluronan (HA) deposition precedes and promotes leukocyte recruitment in intestinal inflammation. Clin Transl Sci. 2008;1:57-61.

33. Wong FW, Chan WY, Lee SS. Resistance to carbon tetrachloride-induced hepatotoxicity in mice which lack CYP2E1 expression. Toxicol Appl Pharmacol. 1998:153:109-18.

34. Edwards MJ, Keller BJ, Kauffman FC, Thurman RG. The involvement of Kupffer cells in carbon tetrachloride toxicity. Toxicol Appl Pharmacol. 1993;119:275-9.

35. Zamara E, Galastri S, Aleffi S, Petrai I, Aragno M, Mastrocola R, Novo E, Bertolani C, Milani S, Vizzutti F. Prevention of severe toxic liver injury and oxidative stress in MCP-1-deficient mice. J Hepatol. 2007:46:230-8.

36. Mitchell C, Couton D, Couty JP, Anson M, Crain AM, Bizet V, Renia L, Pol S, Mallet $\mathrm{V}$, Gilgenkrantz $\mathrm{H}$. Dual role of CCR2 in the constitution and the resolution of liver fibrosis in mice. Am J Pathol. 2009;174:1766-75.

37. Duffield JS, Forbes SJ, Constandinou CM, Clay S, Partolina M, Vuthoori S, Wu S, Lang R, Iredale JP. Selective depletion of macrophages reveals distinct, opposing roles during liver injury and repair. J Clin Invest. 2005;115:56-65.

38. Fallowfield JA, Mizuno M, Kendall TJ, Constandinou CM, Benyon RC, Duffield JS, Iredale JP. Scar-associated macrophages are a major source of hepatic matrix metalloproteinase-13 and facilitate the resolution of murine hepatic fibrosis. J Immunol. 2007;178:5288-95.

39. Welgus $\mathrm{HG}$, Kobayashi DK, Jeffrey JJ. The collagen substrate specificity of rat uterus collagenase. J Biol Chem. 1983;258:14162-5

40. Welgus HG, Grant GA, Sacchettini JC, Roswit WT, Jeffrey JJ. The gelatinolytic activity of rat uterus collagenase. J Biol Chem. 1985;260: 13601-6.

41. Barnes MA, McMullen MR, Roychowdhury S, Madhun NZ, Niese K, Olman MA, Stavitsky AB, Bucala R, Nagy LE. Macrophage migration inhibitory factor is required for recruitment of scar-associated macrophages during liver fibrosis. J Leukoc Biol. 2015:97:161-9.

42. Uchinami H, Seki E, Brenner DA, D'Armiento J. Loss of MMP 13 attenuates murine hepatic injury and fibrosis during cholestasis. Hepatology. 2006;44:420-9.

43. Pritchard MT, Malinak RN, Nagy LE. Early growth response (EGR)-1 is required for timely cell-cycle entry and progression in hepatocytes after acute carbon tetrachloride exposure in mice. Am J Physiol Gastrointest Liver Physiol. 2011;300:G1124-31.

44. Spandidos A, Wang $X$, Wang $H$, Seed B. PrimerBank: a resource of human and mouse PCR primer pairs for gene expression detection and quantification. Nucleic Acids Res. 2010;38:D792-9.

45. Spandidos A, Wang X, Wang H, Dragnev S, Thurber T, Seed B. A comprehensive collection of experimentally validated primers for polymerase chain reaction quantitation of murine transcript abundance. BMC Genomics. 2008;9:633.

46. Wang $X$, Seed B. A PCR primer bank for quantitative gene expression analysis. Nucleic Acids Res. 2003;31, e154. 
47. Decleves AE, Caron N, Voisin V, Legrand A, Bouby N, Kultti A, Tammi Ml, Flamion B. Synthesis and fragmentation of hyaluronan in renal ischaemia. Nephrol Dial Transplant. 2012;27:3771-81.

48. Reddy GK, Enwemeka CS. A simplified method for the analysis of hydroxyproline in biological tissues. Clin Biochem. 1996;29:225-9.

49. Engel CK, Pirard B, Schimanski S, Kirsch R, Habermann J, Klingler O, Schlotte $\checkmark$, Weithmann KU, Wendt KU. Structural basis for the highly selective inhibition of MMP-13. Chem Biol. 2005;12:181-9.

Submit your next manuscript to BioMed Central and we will help you at every step:

- We accept pre-submission inquiries

- Our selector tool helps you to find the most relevant journal

- We provide round the clock customer support

- Convenient online submission

- Thorough peer review

- Inclusion in PubMed and all major indexing services

- Maximum visibility for your research

Submit your manuscript at www.biomedcentral.com/submit 